\title{
FOSTERING BOTTOM-UP ENTREPRENEURSHIP IN EMBRYONIC ECOSYSTEMS: INSIGHTS FROM SMALLHOLDERS
}

\author{
Akiode, M. \\ Aberystwyth Business School, Penglais, Aberystwyth, Wales, UK. \\ Email address: foluke.akiode@gmail.com
}

\begin{abstract}
In embryonic entrepreneurial ecosystems, support policy frameworks seek to revitalize rural communities, alleviate poverty, transform key sectors of the economy and develop local businesses by increasing access to finance among others. However, policy frameworks rarely foster vertical connections across ecosystems particularly from the bottom-up. In some cases, entrepreneurial ecosystem elements do not necessarily address the peculiar needs of entrepreneurial diversity within the ecosystem. Drawing insights from smallholders, this paper seeks to examine the outlook for entrepreneurial opportunities among them and the influence of entrepreneurial ecosystem support on entrepreneurship opportunities outlook. The paper identifies the key drivers of bottom-up entrepreneurship opportunities. The study concludes that fostering bottom-up entrepreneurship among smallholders with a discovery entrepreneurship outlook in embryonic entrepreneurial ecosystems can contribute in helping those in poverty go beyond subsistence entrepreneurship. The paper recommends that entrepreneurial ecosystem elements should be mobilised to offer financial resources and institutional support beyond the current information support available to smallholders.
\end{abstract}

Keywords: Discovery entrepreneurship opportunities, Embryonic ecosystems, Entrepreneurial ecosystems, smallholders, self-employment entrepreneurship opportunities, subsistence entrepreneurship. 


\section{INTRODUCTION}

Entrepreneurial ecosystems represent multiple and overlapping sets of elements - resources and institutions that provide critical resources to entrepreneurs. A sustainable entrepreneurial ecosystem is resilient and adaptive, and is able to accommodate change via problem solving and to achieve beneficial outcomes (Audretsch, Cunningham, Kuratko, Lehmann and Menter, 2019; Kuckertz, 2019). Embryonic entrepreneurial ecosystems support policies often seek the inclusiveness of the different actors and stakeholders in the transformation process. The support policies target diverse groups such as Small and Medium-sized Enterprises (SMEs), occupations (self-employed), regions (underdeveloped, rural), sectors, or individual groups (women, immigrants, and unemployed) (Henrekson and Stenkula, 2010). An under-researched area in the entrepreneurial ecosystem literature is the societal dimension of entrepreneurial systems - how does entrepreneurial diversity e.g., immigrant, youth, people with disability, female etc - contribute to the creation and sustainability of entrepreneurial ecosystems? (Audretsch et al., 2019). Understanding and managing the diversity and fluidity of the actors within embryonic entrepreneurial ecosystems and meeting set objectives are critical for a successful and sustainable ecosystem (Brown and Mason, 2017). Therefore, understanding and meeting the specific needs of diverse and disadvantaged groups contribute to achieving a sustainable entrepreneurial ecosystem.

The entrepreneurial ecosystems literature seeks to understand how the different actors, materials, and goods can be organised in a sustainable and optimal manner (formally and informally) to achieve beneficial outcomes individually and collectively (Audretsch et al., 2019). Entrepreneurship (whether subsistence, local or systemic) is brought to life by individual-level actions which exist within complex socioeconomic structures. That is, it emanates from individual choice or individual action which is regulated by motivation, cognition, perception, desires and judgement (Venkataraman, 1997; Ács, Audretsch, Lehmann, and Licht, 2016). This perspective has been explored to understand the dynamics of diasporans as nonlocal actors in entrepreneurial ecosystems (Fuller-Love and Akiode, 2020). Another area of research that has received less attention from scholars and practitioners is producer-oriented interventions that target improving income-generating capabilities of the poor rather than merely accessing their untapped purchasing power (Ramachandran, Pant, and Pani, 2012). This paper builds on this and seeks to examine the entrepreneurial opportunities outlook among smallholders and the role entrepreneurial ecosystems elements could play in fostering bottom-up entrepreneurial activity. It draws insights from smallholder households - a diverse group of agricultural producers who mostly live in poor, rural and underdeveloped areas. The two research questions this paper seek to address are: 
a. What factors influence the entrepreneurship opportunities outlook among smallholders?

b. To what extent does the entrepreneurial ecosystem support, influence entrepreneurship opportunities outlook among smallholders?

\section{Hypotheses of the Study}

$\mathrm{HO}_{2}$ : There is no relationship between the realities of smallholders and self-employment entrepreneurship opportunities outlook.

$\mathrm{HO}_{\mathrm{b}}$ : There is no relationship between the realities of smallholders and discovery entrepreneurship opportunities outlook.

$\mathrm{H}_{\mathrm{c}}$ : There is a relationship between entrepreneurial ecosystem support and self-employment opportunities outlook

$\mathrm{H} 0_{d}$ : There is a relationship between entrepreneurial ecosystem support and discovery opportunities outlook

\section{LITERATURE REVIEW}

\section{Engaging Smallholders in Entrepreneurship}

Smallholders are a diverse group that play a crucial role in achieving entrepreneurial ecosystems objectives. This group is particularly relevant to discussions about entrepreneurial ecosystem objectives aimed at transforming the agriculture sector, revitalizing rural communities and alleviating poverty. The smallholder population is part of the world population with a per capita income of less than $\$ 2$ per day (Prahalad, 2012). Smallholder farming drives the rural area economy and smallholder farmers dominate the agriculture sector. In developing economies, smallholder farmers are the primary sources of agricultural products in the supply chains of both SMEs and larger businesses. These farmers are agricultural producers with diverse financial needs and varied sources of income. Engaging smallholders in entrepreneurship would improve their income-generating capabilities and help alleviate poverty. However, as a low-income-producer-population, they are faced with a myriad of resource challenges, among which is their limited access to credit (Reficco and Márquez, 2012).

According to the National Bureau of Statistics (2010), over $56 \%$ of Nigerians living in rural areas live below the poverty line of USD 2 per day - the widely accepted median poverty level for all developing economies (Bruton et al., 2015). The poor who live in rural areas generate their livelihoods primarily from smallholder farming and rural activities. Within the Nigeria entrepreneurial ecosystem is the One Local Government One Product (OLOP) programme 
established in April 2009. The programme seeks to revitalize the rural economy, improve employment opportunities and alleviate poverty in the rural areas. Smallholders ought to be critical actors in achieving the OLOP objectives. However, platforms to link and encourage such collaborations within the entrepreneurial ecosystem segments are lacking (Fate Foundation, 2016).

\section{Entrepreneurial Activity and Embryonic Ecosystems}

In embryonic entrepreneurial ecosystems, policy frameworks are directed at supporting entrepreneurship and stimulating business activities. While in scale-up entrepreneurial ecosystems the emphasis is on the quality of firms rather than quantity. Therefore, it is focused on enabling entrepreneurship rather than supporting it (Henrekson and Stenkula, 2010; Brown and Mason, 2017). Entrepreneurial support policy is an incentive for increased employment, poverty alleviation, growth, or innovation output. Embryonic entrepreneurial ecosystems are characterised by entrepreneurial support policy frameworks. The aims of such frameworks include; revitalizing rural communities, transforming key sectors of the economy and developing local businesses by increasing access to finance. By developing local entrepreneurship, the living conditions of the poor are improved and they are brought closer to mainstream markets as producers, or business partners (Prahalad, 2012; Reficco and Márquez, 2012).

A distinction between the notions of systemic entrepreneurship and local entrepreneurship helps to understand limits on entrepreneurial activity (Sautet, 2013). Systemic entrepreneurship enables the exploitation of opportunities beyond the initial local level through the capture of economies of scale and scope, and through the establishment of organisational structures. The framework conditions and systemic conditions of entrepreneurial ecosystems lead to productive entrepreneurship and new value creation (Stam, 2015).

Local entrepreneurship rests on the exploitation of local opportunities and on simple organisational structures that do not lead to economies of scale and scope such as those found in growing firms (Sautet, 2013). Subsistence or necessity entrepreneurship are the types of entrepreneurial efforts encouraged in centers of extreme poverty by many individuals, nonprofits and governments, to create little substantial value for the person and the society (Bruton

et al., 2015). There are overlaps in both local entrepreneurship and subsistence (necessity) entrepreneurship. However, in the former, it is the scope of the entrepreneurial opportunity in the market that limits the growth of the business, the latter is limited by the motivation of the individual (Sautet, 2013). 
Oftentimes, policy frameworks rarely attempt to help foster vertical connections across ecosystems (Brown and Mason, 2017). Hence, these policy frameworks do not always address peculiar needs of the targets. Thereby, failing to effect the desired transformation in the key sectors. The need for ecosystem frameworks that protect and support local businesses emerged as a result of the inherent constraints small businesses experience relative to large businesses e.g. cost, network, knowledge and learning disadvantages. Therefore, ecosystem support comes in forms such as, provision tax-based incentives, government procurement programs, investment in education and research, support for entrepreneurship by government agencies and the removal of bureaucratic hurdles (Gnyawali and Fogel, 1994). The creation of specific government agencies in a range of support programs and subsidies provide support frameworks that compensate for microeconomic side-effects such as scale-economies or other cost and information disadvantages (Henrekson and Stenkula, 2010). Most successful ecosystems build upon activities which they have prior core competencies or advantages, and ensuring that these existing competencies are developed is vitally important. Doing otherwise amounts to ignoring the evolutionary logic and path-dependencies which shape their home environments (Brown and Mason, 2017).

\section{Bottom-Up Opportunities in Embryonic Ecosystems}

One of the challenges of an embryonic entrepreneurial ecosystem is the presence of significant gaps that lead to ecosystem programmes falling short of meeting the set objectives (Brown and Mason, 2017). A grassroot perspective is important because not every component of an entrepreneurial ecosystem or relationship among components can be managed top-down (Kuckertz, 2019). For example, a top-down strategy in entrepreneurial ecosystems does not make it easy to trace gaps in system performance back to specific, well-defined market and structural failures (Ács et al., 2016). However, a bottom-up strategy would help to identify gaps and meet objectives. Particularly, in the case where the objective is to alleviate poverty and develop local businesses. A bottom-up strategy in this instance, would focus on grassroots development. This would be through community involvement - centred around issues such as the needs, the constraints, and the unique resources of a majority [smallholders] that lives outside the confines of the formal economy but who nonetheless are key producers and relevant to the formal economy (Ramachandran et al., 2012). According to Faist (2008) such a strategy shifts the focus away from growth and towards issues of redistribution and equity, decentralisation and localisation. Grassroots efforts in entrepreneurial ecosystems cultivate local entrepreneurial networks, which create a regional culture that is risk tolerant and supportive of new ventures (Mack and Meyer, 2016). 
The settings where poverty alleviation initiatives unfold tend to be fractured and opaque, preventing resources and information from flowing seamlessly. For example, in some settings, inclusive networks for easier connection of supply and demand are absent, funding entities transfer resources to local peasants for technical training and infrastructure but do not engage storage and processing companies, distributors or retailers (Reficco and Márquez, 2012).

Access to ecosystems is a substantive outcome that has a significant poverty-alleviation consequence (Ramachandran et al., 2012). Building new ventures that have growth potential facilitates poverty reduction (Bruton et al., 2015). However, poverty reduction outcomes may not be achievable without proper management of diversity and fluidity of the actors within embryonic entrepreneurial ecosystems. The diversity an entrepreneurial ecosystem displays and its ability to learn, fosters grassroots development. As entrepreneurial ecosystems evolve, the importance and relative strength of its components changes, as well as the policies necessary to sustain the systems over time (Mack and Meyer, 2016).

Research is making it clearer that a concern for entrepreneurship and its supporting institutions, in addition to investments in infrastructural projects and education, can yield a strong impact on poverty. This is particularly true when people living in poverty are supported to exploit entrepreneurial opportunities and move from subsistence entrepreneurship that 'generates little hope for more substantial improvement in their standards of living' (Bruton et al., 2015: p3). A bottom-up-producer-oriented entrepreneurial ecosystem intervention focuses on the specific constraints faced by producers and how these challenges are being overcome by the firms that partner with them (Ramachandran et al., 2012). Much of the work on entrepreneurial ecosystems strongly corresponds with seeking to understand entrepreneurship from a systemic perspective that encompasses multiple actors, institutions and processes (Brown and Mason, 2017). Therefore, for an embryonic entrepreneurial ecosystem with a focus on transforming the agricultural sector and revitalizing rural communities. It is important to understand how the ecosystem elements or components can benefit smallholders as they explore entrepreneurial opportunities that bring them closer as contributors to mainstream markets.

\section{Entrepreneurial Ecosystem and Poverty Contexts}

The set of interdependent actors and elements in an entrepreneurial ecosystem are governed in such a way that entrepreneurial activity contributes directly or indirectly to the economy (Stam, 2015). Entrepreneurial ecosystem elements are the components or attributes that make up the ecosystem and help to differentiate the outcomes of a successful ecosystem. The interactions of entrepreneurial ecosystems elements influence the creation, discovery and exploitation of entrepreneurial opportunities (Spigel, 2017; Brown and Mason, 2017). The integrative model of entrepreneurial ecosystems consists of ten elements representing 
institutional arrangements and resource endowments (Stam and van de Ven, 2019). These ecosystem elements are complementary to individual choice and actions of entrepreneurs. This is because the extent to which new value is created is dependent on the entrepreneurial opportunities taken by individuals.

Entrepreneurial opportunities consist of a set of ideas, beliefs, and actions (Venkataraman, 1997) that create situations in which "new goods, services, raw materials, markets, and organising methods can be introduced for profit" (Eckhardt and Shane, 2010 p.49). Therefore, the interactions between ecosystem elements and individual choice and actions of entrepreneurs, help in increasing the scope for entrepreneurial opportunities and wealth creation. Context regulates opportunities and personal feasibility considerations as well as the outcomes of entrepreneurial action (Ács et al., 2014). Entrepreneurship is primarily undertaken and driven by the individual and entrepreneurial ecosystems are fundamentally resource allocation systems driven by individual entrepreneurship choice variables and institutional settings (Ács et al., 2016).

There are three commonly exploited types of opportunities in settings of abject poverty. These opportunities are; self-employment opportunities, discovery opportunities and creation opportunities (Alvarez and Barney, 2014). Self-employment opportunities exist in pre-existing markets or industries whether the entrepreneur exploits them or not and requires low levels of human capital. Discovery opportunities exist independent of the entrepreneur but can only be observed through alertness and deep experience in the market. Creation opportunities exist when the entrepreneur enacts it and the entrepreneurial process is characterised by circulation of tacit knowledge and learning.

\section{Theoretical Framework}

The conceptual framework for this paper draws on entrepreneurship theory on opportunities that consider the implications of human capital, property rights, and financial capital for wealth creation (Jones et al., 2011; Alvarez and Barney, 2014).

\section{Smallholders' realities and entrepreneurship opportunities outlook}

Entrepreneurship opportunities generate economic wealth when competition is not perfect in factor or product markets (Alvarez and Barney, 2014). In this paper, entrepreneurial outcome is viewed from the perspective of entrepreneurship opportunities outlook of smallholders. Selfemployment opportunities lead to subsistence entrepreneurship which has limited potential. Bruton et al. (2015) point out that subsistence entrepreneurship generates little hope for more substantial improvement in the standards of living. It is rarely scalable and rarely a source of employment. The abjectly poor exploiting self-employment opportunity will typically have low 
levels of human capital or education and access to financial capital. They rarely have the property rights protection that is needed in order to exploit significant wealth-creating opportunities (Alvarez and Barney, 2014). Property rights tend to be informal, underdeveloped and come through communal or neighbourhood associations (Bruton et al., 2015). Therefore, such smallholders with self-employment entrepreneurship opportunities outlook would typically do so to make ends meet. This type of entrepreneurship is supported by early-stage embryonic ecosystems. Although there might be strong influence of microlending, NGOs and government programs on subsistence entrepreneurship, it does not yield a strong impact on poverty. Prahalad (2012) points out that one of the ways ecosystems support the creation of new markets is by providing subsistence farmers with weather and price information using a mobile phone. However, the transformation of subsistence farmers into world-class suppliers is not automatic. It entails a sustained program of training in both technical and managerial aspects of production (Reficco and Márquez, 2012).

Discovery entrepreneurship opportunities are expected to flourish in evolving embryonic ecosystems. Those with this outlook have deep experience in the market. In addition to the ecosystem support available to those living in poverty, such opportunities are expected to lead to local entrepreneurship. As market opportunities are developing, smallholders with discovery entrepreneurship opportunities outlook would be seeking to expand and exploit local entrepreneurship. They would be those seeking opportunities to expand, looking at new products and markets. Therefore, discovery opportunities lead to local entrepreneurship, a move beyond subsistence entrepreneurship.

Creation entrepreneurship opportunities will be exploited where embryonic ecosystems have developed enough to start enabling the growth of local enterprises. One of the characteristics of scale-up entrepreneurial ecosystems is the high levels of nonlocal actors e.g. transnational entrepreneurs (Brown and Mason, 2017). In developing contexts, diasporas (remittances) are potential 'patient capital' for co-created opportunities (Alvarez and Barney, 2014). In addition, in scale-up ecosystems there are substantial levels of re-cycling and experiential learning. Therefore, creation entrepreneurship opportunities are expected to lead to systemic entrepreneurship.

However, both discovery and creation opportunities are expected to be influenced by entrepreneurial ecosystem elements. This is because entrepreneurs are only able to exploit such opportunities within the context of a well-developed economic infrastructure, with defined and enforced property rights, sophisticated financial markets, and developed human capital (Alvarez and Barney, 2014). 
A key component of entrepreneurial ecosystems is culture in terms of positive societal norms and attitudes towards entrepreneurship (Brown and Mason, 2017). Context and personal feasibility considerations (Ács et al., 2014) explored through sets of ideas, beliefs, and actions (Venkataraman, 1997) regulate opportunities. Therefore, the present realities of smallholders will enable a better understanding of the factors that drive the entrepreneurship opportunities outlook of smallholders. Also, in contexts of abject poverty, the likelihood that an individual will participate in and benefit from entrepreneurship increases when they have access to financial capital, property rights and human capital (Alvarez and Barney, 2014). Therefore, this paper explores entrepreneurship opportunities outlook through the realities of smallholders in terms of human capital (skills, knowledge, experience, education), financial capital (means to invest in activities that do not yet deliver financial means) and farming property rights (land ownership).

\section{Influence of entrepreneurial ecosystem support on the entrepreneurship opportunities outlook of smallholders}

An entrepreneurial ecosystem with an objective of poverty alleviation is expected to have a focus on grassroot development. A bottom-up focus helps to meet the set objectives because it is easier to spot gaps and adapt to the needs of the ecosystem (Kuckertz, 2019). In entrepreneurial ecosystems, human capital, financial capital and property rights are resource endowments (elements) and they are embedded in the formal institutional arrangements (Stam and van de Ven, 2019). In an embryonic entrepreneurial ecosystem, financial capital support comes through microlending, banks, NGOs; human capital support, government programs for skills acquisition, reducing cost and information disadvantages, documentation of property rights etc. Also, in such ecosystems policy plays a critical role and typically focuses on increasing resources, particularly access to finance to support those in poverty beyond subsistence entrepreneurship and improving local entrepreneurship. Therefore, the ecosystem elements are expected to influence the nature and extent of entrepreneurial opportunities being sought. That is, the ecosystem support available to smallholders is expected to drive discovery opportunities. Therefore, we explore the differences between entrepreneurial ecosystem support and the entrepreneurial opportunities outlook of smallholders.

\section{METHODOLOGY}

The analysis for this paper made use of data from the Consultative Group to Assist the Poor (CGAP) Smallholder Household Survey in Nigeria (Anderson and World Bank, 2016). The questionnaires were pretested on 5-7 November 2016 and the data collection was carried out between 15 November and 9 December 2016. The questionnaires were translated into Igbo, Hausa, Yoruba, and Pidgin. Smallholders' households are defined as those with up to 5 
hectares or farmers who have less than: 50 heads of cattle or 100 goats/sheep/pigs or 1,000 chickens and agriculture provides a meaningful contribution to the household livelihood, income, or consumption. A sample size of 2773 household members was used for the study.

Table 1: Breakdown of respondents

\begin{tabular}{lccccccc}
\hline & $\begin{array}{c}\text { North } \\
\text { Central }\end{array}$ & $\begin{array}{c}\text { North } \\
\text { East }\end{array}$ & $\begin{array}{c}\text { North } \\
\text { West }\end{array}$ & $\begin{array}{c}\text { South } \\
\text { East }\end{array}$ & $\begin{array}{c}\text { South } \\
\text { South }\end{array}$ & $\begin{array}{c}\text { South } \\
\text { West }\end{array}$ & Total \\
\hline $\begin{array}{l}\text { Eligible household } \\
\text { members }\end{array}$ & 490 & 490 & 785 & 369 & 419 & 473 & 3,026 \\
$\begin{array}{l}\text { Eligible household } \\
\text { members }\end{array}$ & 472 & 432 & 678 & 347 & 400 & 444 & 2,773 \\
$\begin{array}{l}\text { interviewed } \\
\text { Response rate }\end{array}$ & $96 \%$ & $88 \%$ & $86 \%$ & $94 \%$ & $95 \%$ & $94 \%$ & $92 \%$ \\
\hline
\end{tabular}

SOURCE: (CGAP Working Paper, 2017 pp.13)

The sample was designed to produce national estimates and estimates for the six geopolitical zones of Nigeria. The respondents were randomly selected adults in the household who contribute to the household income or participate in its agricultural activities. The questionnaire framework covered; demographics, agricultural activities, household economics, mobile phones and formal and informal financial tools. The questions covered in the household economics explored how smallholders' aspirations match their realities as well as their actions and obligations (CGAP Working Paper, 2017).

\section{DATA ANALYSIS AND INTERPRETATION}

The analysis looks at entrepreneurship opportunities outlook as being dependent on the realities of smallholders and entrepreneurial ecosystem support available to smallholders. The realities variables are questions that reflect the implications of human capital, property rights, and financial capital on entrepreneurship opportunities. The entrepreneurial ecosystem support variables reflect entrepreneurial ecosystem support through government agencies and NGOs, offering a range of support that compensate for cost and information disadvantages, mobile phones with weather and price information. The dependent variables - entrepreneurship opportunities outlook, were captured by two questions which reflect self-employment and discovery entrepreneurship opportunities (Table 2). 
Table 2: Final structure and decisions for entrepreneurship outlook variables

\begin{tabular}{llccc}
\hline & Components and items & $\begin{array}{c}\text { Item total } \\
\text { correlation }\end{array}$ & Alpha value & Decision \\
\hline $\begin{array}{l}\text { Self-employment } \\
\text { opportunities outlook } \\
1\end{array}$ & & 0.923 & Retain \\
$\begin{array}{l}\text { Discovery opportunities } \\
\text { outlook }\end{array}$ & $\begin{array}{l}\text { I just work to make ends } \\
\text { meet }\end{array}$ & 0.869 & & \\
2 & $\begin{array}{l}\text { I just want to expand my } \\
\text { agricultural activities by } \\
\text { looking at new products } \\
\text { and/or markets }\end{array}$ & 0.869 & & \\
& & & \\
\hline
\end{tabular}

\section{Factor analysis using the Principal Component Analysis (PCA) Method}

A principal component analysis (PCA) method was used to carry out an exploratory factor analysis. Components were selected based on eigenvalue $>1$ which is the coefficient of the principal components which shows the direction with the greatest variation (Kemalbay and Korkmazoğlu, 2014). For the smallholder realities variables, two variables were dropped in the first step of the factor analysis because their communality values were below 0.50 . The remaining ten variables formed three components which accounts for $83.59 \%$ of the total variance and the reliability coefficients. The three components were named: farming and property rights, education, and access to finance respectively as shown in Table 3 below: 
Table 3: Final structure and decisions for smallholder realities factors

\begin{tabular}{|c|c|c|c|c|}
\hline & Components and items & $\begin{array}{l}\text { Item total } \\
\text { correlation }\end{array}$ & Alpha value & Decision \\
\hline Component 1 & & & 0.928 & Retain \\
\hline \multicolumn{5}{|l|}{ Farming and } \\
\hline \multicolumn{5}{|c|}{ Property Rights } \\
\hline 1 & $\begin{array}{l}\text { Farm considered to be a } \\
\text { business }\end{array}$ & 0.908 & & \\
\hline 2 & Form of land ownership & 0.908 & & \\
\hline 3 & Size of land owned & 0.889 & & \\
\hline 4 & $\begin{array}{l}\text { Size of land rented, borrowed } \\
\text { or have the right to use units }\end{array}$ & 0.713 & & \\
\hline 5 & Number of years in farming & 0.688 & & \\
\hline Component 2 & & & 0.757 & Retain \\
\hline \multicolumn{5}{|l|}{ Education } \\
\hline 6 & Ever attended school & 1.000 & & \\
\hline 7 & $\begin{array}{l}\text { Completed highest grade } \\
\text { attended }\end{array}$ & 0.998 & & \\
\hline 8 & Highest grade attended & 0.998 & & \\
\hline \multicolumn{5}{|l|}{ Component 3} \\
\hline \multicolumn{5}{|c|}{ Access to finance } \\
\hline 9 & $\begin{array}{l}\text { My savings are larger than my } \\
\text { debts }\end{array}$ & 0.394 & & \\
\hline 10 & $\begin{array}{l}\text { I spend less money than I } \\
\text { make each month }\end{array}$ & 0.394 & & \\
\hline
\end{tabular}

SOURCE: CGAP Survey, 2016.

Bartlett's test $(p<0.05$ at .0001$)$ shows that the correlation matrix is significantly different from an identity matrix and therefore suitable for structure detection. At $0.814 \mathrm{KMO}$ is greater than .60 indicating that the items are sufficient for each component or factor. The exploratory factor 
analysis was again repeated for the ecosystem support variables and the final structures are shown in Table 4.

Table 4: Final structure and related decisions for entrepreneurial ecosystem support

\begin{tabular}{|c|c|c|c|c|}
\hline & Components and items & $\begin{array}{l}\text { Item total } \\
\text { correlation }\end{array}$ & $\begin{array}{l}\text { Alpha } \\
\text { value }\end{array}$ & Decision \\
\hline $\begin{array}{l}\text { Component } 1 \\
\text { Information } \\
\text { support }\end{array}$ & & & 0.923 & Retain \\
\hline 1 & $\begin{array}{l}\text { Use of sources of information for } \\
\text { agricultural activities-Rural } \\
\text { development agents / NGOs }\end{array}$ & 0.856 & & \\
\hline 2 & $\begin{array}{l}\text { Use of sources of information for } \\
\text { agricultural activities-Government } \\
\text { officials / Agricultural extension } \\
\text { officer }\end{array}$ & 0.856 & & \\
\hline 1 & $\begin{array}{l}\text { Ability to buy and sell on a mobile } \\
\text { phone }\end{array}$ & -0.004 & & delete \\
\hline 2 & $\begin{array}{l}\text { Ability to access financial services on } \\
\text { a mobile phone }\end{array}$ & -0.005 & & delete \\
\hline 3 & $\begin{array}{l}\text { Access to: Growth Enhancement } \\
\text { Support Scheme (GESS) by the } \\
\text { Federal Ministry of Agriculture and } \\
\text { Rural Development }\end{array}$ & 0.071 & & delete \\
\hline 4 & $\begin{array}{l}\text { Access to: Price Information by } \\
\text { Novus Agro }\end{array}$ & 0.156 & & delete \\
\hline
\end{tabular}

SOURCE: CGAP Survey, 2016.

\section{Relationship between smallholder realities and self-employment entrepreneurship opportunities outlook}

A multiple regression was used to find the relationship between smallholder realities and selfemployment opportunities outlook. The smallholder realities variables were used as the independent variables while the self-employment outlook was used as the dependent variable. The results in Table 5 indicate that there is a significant relationship between smallholder realities and self-employment opportunities outlook; this is reflected in the F value of 1015.09 which is significant at 0.000 . There is also a positive relationship between the number of years in farming and the form of land ownership which are significant at 0.000 and 0.025 respectively. 
Table 5: Smallholder realities and self-employment opportunities outlook

\begin{tabular}{lcccc}
\hline & $\begin{array}{c}\text { Unstandardized } \\
\text { Coefficients } \\
\text { B }\end{array}$ & Std. Error & t & Sig. \\
\hline (Constant) & -0.415 & 0.03 & -13.885 & 0.000 \\
Completed highest grade attended & 0.001 & 0.003 & 0.378 & 0.705 \\
Number of years in farming & 0.031 & 0 & 65.501 & 0.000 \\
I spend less money than I make each & 0.002 & 0.012 & 0.149 & 0.882 \\
month & & & & \\
My savings are larger than my debts & -0.002 & 0.01 & -0.202 & 0.84 \\
Form of land ownership & 0.002 & 0.001 & 2.25 & 0.025 \\
Size of land own & 0 & 0.001 & -0.795 & 0.427 \\
Size of land_rent, borrow or have the & -0.001 & 0 & -1.794 & 0.073 \\
right to use_units & & & & \\
Farm considered to be a business & -0.001 & 0.001 & -1.221 & 0.222 \\
Highest grade attended & -0.001 & 0.003 & -0.182 & 0.855 \\
F =1015.09 (Sig. = 0.000) & & & & \\
R = 0.876 (R-Square = 0.768) & & & & \\
\hline SOURCE: CGAP Survey, 2016. Significance level = 0.05 & & & \\
\hline
\end{tabular}

\section{Relationship between smallholder realities and discovery entrepreneurship opportunities outlook}

It has been argued that subsistence entrepreneurship does not yield a strong impact on poverty. Therefore, if exploiting discovery opportunities could create an impact, the factors that influence such an outlook could be different from those of self-employment opportunities. The results of the regression to find the relationship between smallholder realities and discovery opportunities outlook are presented in Table 6. The $F$ value of 1566.62 is significant at 0.000 , indicating that there is a significant relationship between smallholder realities and discovery opportunities outlook. 
Table 6: Smallholders realities and discovery opportunities outlook

\begin{tabular}{lcccc}
\hline & $\begin{array}{c}\text { Unstandardized } \\
\text { Coefficients } \\
\text { B }\end{array}$ & Std. Error & $\mathbf{t}$ & Sig. \\
& -0.503 & 0.025 & -20.037 & 0.000 \\
\hline Constant) & 0.001 & 0.003 & 0.271 & 0.787 \\
Completed highest grade attended & 0.032 & 0 & 80.935 & 0.000 \\
Number of years in farming & $1.30 \mathrm{E}-02$ & 0.01 & 1.273 & 0.203 \\
I spend less money than I make each & & & & \\
month & 0.011 & 0.008 & 1.341 & 0.18 \\
My savings are larger than my debts & 0.002 & 0.001 & 2.4 & 0.016 \\
Form of land ownership & 0 & $0.00 \mathrm{E}+00$ & 0.281 & 0.779 \\
Size of land owned & 0 & 0 & -1.403 & 0.161 \\
Size of land rented, borrowed or have & & & & \\
the right to use units & -0.001 & 0.001 & -2.059 & 0.04 \\
Farm considered to be a business & 0 & 0.003 & 0.047 & 0.963 \\
Highest grade attended & & & & \\
F = 1566.62 (Sig. $=0.000$ ) & & & & \\
R = 0.914 (R-Square = 0.836) & & & & \\
\hline SOURCE: CGAP Survey, 2016. Significance level = 0.05 & & & & \\
\hline
\end{tabular}

There is also a positive relationship between the number of years in farming, the form of land ownership and considering farming to be a business. They are significant at 0.0000 .016 and 0.04 respectively. The two variables dropped from the initial component analysis were finance variables. Further stand-alone observation shows that $81 \%$ of the smallholders do not have a personal bank account registered in their name. None of the remaining finance variables is significantly related to either self-employment or discovery entrepreneurship opportunities outlook.

\section{Relationship between ecosystem support and entrepreneurship opportunities outlook}

The results presented in Table 7 show that there is a significant relationship between ecosystem support and entrepreneurship opportunities outlook. This is true for selfemployment entrepreneurship opportunities outlook with $\mathrm{F}$ value $=1407.42$ which is significant at 0.000 . 
Table 7: Ecosystem support and self-employment opportunities outlook

\begin{tabular}{|c|c|c|c|c|}
\hline & $\begin{array}{c}\text { Unstandardized } \\
\text { Coefficients } \\
\text { B } \\
\end{array}$ & Std. Error & $\mathrm{t}$ & Sig. \\
\hline (Constant) & -0.414 & 0.015 & & 0.000 \\
\hline $\begin{array}{l}\text { Use of sources of information for } \\
\text { agricultural activities-Rural development } \\
\text { agents / NGOs (A44_9) }\end{array}$ & 0.009 & 0.001 & 0.306 & 0.000 \\
\hline $\begin{array}{l}\text { Use of sources of information for } \\
\text { agricultural activities-Government officials / } \\
\text { Agricultural extension officer (A44_11) }\end{array}$ & 0.013 & 0.001 & 0.43 & 0.000 \\
\hline$F=1407.42($ Sig. $=0.000)$ & & & & \\
\hline$R=0.710(R-S q u a r e=0.504)$ & & & & \\
\hline
\end{tabular}

SOURCE: CGAP Survey, 2016. Significance level $=0.05$

Discovery entrepreneurship opportunities outlook results presented in Table 8 show that the $F$ value $=1701.95$ is also significant at 0.000 .

Table 8: Ecosystem support and discovery opportunities outlook

\begin{tabular}{|c|c|c|c|c|}
\hline & $\begin{array}{l}\text { Unstandardized } \\
\text { Coefficients } \\
\text { B }\end{array}$ & Std. Error & $t$ & Sig. \\
\hline (Constant) & $-4.32 \mathrm{E}-01$ & 0.015 & -29.327 & 0.000 \\
\hline $\begin{array}{l}\text { Use of sources of information for } \\
\text { agricultural activities-Rural development } \\
\text { agents / NGOs (A44_9) }\end{array}$ & 0.009 & 0.001 & 12.146 & 0.000 \\
\hline $\begin{array}{l}\text { Use of sources of information for } \\
\text { agricultural activities-Government officials / } \\
\text { Agricultural extension officer (A44_11) } \\
F=1701.95 \text { (Sig. }=0.000) \\
R=0.743 \text { (R-Square }=0.551)\end{array}$ & 0.014 & 0.001 & 19.071 & 0.000 \\
\hline
\end{tabular}

In both cases self-employment and discovery opportunities outlook and entrepreneurial ecosystem support were significant at 0.000 . Similar to the access to finance variables, the four entrepreneurial ecosystem support variables; access to Growth Enhancement Support Scheme (GESS) by the Federal Ministry of Agriculture and Rural Development, access to price information by Novus Agro, ability to buy and sell on a mobile phone and access to financial 
services on a mobile phone were all deleted from the structure because the variable lacked a Cronbach alpha and an item-total correlation. A standalone review of the variables showed that $3.9 \%$ of the total respondents answered the question about access to the GESS and only $0.6 \%$ of them have access. $1.3 \%$ of the total respondents answered the question about access to price information by Novus Agro and only $0.2 \%$ of them have access. Out of the total respondents, only $7 \%$ can buy and sell on mobile phones while only $5 \%$ of the total respondents can access financial services on a mobile phone.

\section{DISCUSSION OF FINDINGS}

The data analysis has helped to gain more insight about the entrepreneurship opportunities outlook among smallholders and also the entrepreneurial ecosystem elements that support entrepreneurship opportunities. Theoretically, the likelihood of participating and benefitting from entrepreneurship increases when there is access to property rights, human capital and financial capital (Alvarez and Barney, 2014). Also, it is believed that exploiting discovery entrepreneurship opportunities is a move away from subsistence entrepreneurship that has little to offer in terms of substantial improvement in the standards of living (Bruton et al., 2015). The findings of this paper in terms of property rights show that there is a significant relationship between the outlook for discovery entrepreneurship opportunities and land ownership. While this is also significant for those with self-employment outlook, among those with discovery entrepreneurship opportunities outlook, there are more smallholders who have individual ownership of hectares and acres with lease or certificate or with rights under customary law compared to those with self-employment entrepreneurship opportunities outlook. This finding highlights a key distinction between those exploiting discovery entrepreneurship opportunities and self-employment entrepreneurship opportunities. In the latter, property rights tend to be informal and through communal or neighbourhood associations (Bruton et al., 2015).

In terms of human capital, experience seems more critical than formal education. The number of years spent in farming is a significant factor that influences both self-employment and discovery entrepreneurship opportunities outlook. However, there are more smallholders with discovery entrepreneurship opportunities outlook, who have been farming for over 10 years compared to those with self-employment opportunities outlook. In both cases, there is no significant relationship between formal education and entrepreneurship opportunities outlook. Generally, there are more smallholders who have primary education as their highest completed grade.

The relationship between smallholder realities and entrepreneurship opportunities outlook in terms of seeing farming to be a business was only significant for smallholders with discovery entrepreneurship outlook. Unlike smallholders with self-employment opportunities outlook - 
who see farming as a means to an end, whereas, smallholders with discovery entrepreneurship opportunities outlook consider farming to be a business.

Financial capital is required to exploit wealth-creating opportunities (Alvarez and Barney, 2014). There is a substantial finance need among the smallholders. The dream of improving the living conditions of the poor and bringing them closer to mainstream markets as producers, or business partners (Prahalad, 2012; Reficco and Márquez, 2012), will remain but a dream. Access to finance is deemed crucial for the emergence of entrepreneurship and financial capital needed for exploiting discovery entrepreneurship opportunities can be accessed in entrepreneurial ecosystems (Stam and van de Ven, 2019). However, unless there is a bottomup entrepreneurship opportunities perspective in embryonic entrepreneurial ecosystems, smallholders seeking to exploit discovery entrepreneurship opportunities will continue to be limited by the lack of access to needed capital.

In terms of the relationship between entrepreneurial ecosystems support and entrepreneurship opportunities outlook, the two variables significantly related to both outlooks are informational in nature. Rural development agents, NGOs and government officials /agricultural extension officers are the sources of information for opportunity recognition. Although, it is believed that access to mobile phones is one of the ways ecosystems can support the creation of new markets (Prahalad, 2012). As is evident from the analysis, smallholders do not enjoy such support. Even though information is important, entrepreneurial ecosystem elements should be mobilised to offer access to financial resources and institutional support beyond providing information to smallholders particularly to those with a discovery entrepreneurship opportunities outlook.

\section{CONCLUSION AND RECOMMENDATIONS}

This paper explored the entrepreneurial opportunities outlook of smallholders, a group of actors critical to an embryonic entrepreneurial ecosystem's objectives of revitalising rural economy and alleviating poverty. Fostering bottom-up opportunities in embryonic ecosystems requires paying attention to the three key drivers of wealth creation in areas of abject poverty namely: financial capital, human capital and property rights. A bottom-up entrepreneurship opportunities perspective in embryonic ecosystems would nurture exploiting discovery opportunities which would contribute to helping those in poverty go beyond subsistence entrepreneurship.

The paper explored the influence of smallholders' realities on their entrepreneurship opportunities outlook. Land ownership has a significant relationship with discovery entrepreneurship opportunities outlook. Experience in terms of numbers of years of farming, has a more significant influence than education among smallholders with discovery 
entrepreneurship outlook. Access to finance has no significant relationship with discovery opportunities outlook. Entrepreneurial ecosystem support is significant in terms of information support but there is a need to configure ecosystem elements to address access to finance and training.

Although, exploring entrepreneurship opportunities outlook is not the same as the actual exploitation of entrepreneurship opportunities. However, the findings of this paper have identified that access to finance is limited and that ecosystem system support available is limited to only informational support. These are some areas that embryonic entrepreneurial ecosystems wishing to pursue poverty alleviation and wealth creation support interventions should focus on.

\section{REFERENCES}

Ács, Z. J., Autio, E., \& Szerb, L. (2014). National systems of entrepreneurship: Measurement issues and policy implications. Research Policy, 43(3), 476-494.

Ács, Z. J., Audretsch, D. B., Lehmann, E. E., \& Licht, G. (2016) National systems of entrepreneurship. Small Business Economics, 46, 527-535. DOI: https://doi.org/10.1007/s11187-016-9705-1.

Alvarez, S.A., \& Barney, J.B. (2014). Entrepreneurial opportunities and poverty alleviation, Entrepreneurial Theory and Practice. (pp.159-184). DOI: https://doi.org/10.1111/etap.12078.

Anderson, J., and World Bank (2016). CGAP Smallholder household survey in Nigeria 2016, Building the evidence base on the agricultural and financial lives of Smallholder Households. Washington, D.C.: The World Bank, CGAP (Consultative Group to Assist the Poor).

Audretsch, D.B., Cunningham, J.A., Kuratko, D.F., Lehmann, E.E., \& Menter, M. (2019). Entrepreneurial ecosystems: economic, technological, and societal impacts, The Journal of Technology Transfer, 44, 313-325. DOI: https://doi.org/10.1007/s10961018-9690-4.

Brown, R. \& Mason, C. (2017). Looking inside the spiky bits: A critical review and Conceptualisation of Entrepreneurial Ecosystems. Small Business Economics, 49, 11 30. DOI: https://doi.org/10.1007/s11187-017-9865-7.

Bruton, G.D., Ahlstrom, D., \& Si, S. (2015). Entrepreneurship, poverty, and Asia: Moving beyond subsistence entrepreneurship. Asia Pacific Journal of Management, 32,1-22 DOI: https://doi.org/10.1007/s10490-014-9404-x.

CGAP Working Paper (2017). CGAP Smallholder Household Surveys User Guide to the Data Set for Nigeria. 
Çilana, Ç. A., \& Can, M. (2014). Measuring Factors Effecting MBA Students' Academic Performance by Using Categorical Regression Analysis: A Case Study of Institution of Business Economics, Istanbul University, Procedia - Social and Behavioral Sciences, $122,405-409$.

Eckhardt, J.T. \& Shane, S. (2010). An update to the individual-opportunity nexus, In Ács, Z.J. and Audretsch, D.B. (eds.). Handbook of entrepreneurship research: An Interdisciplinary survey and introduction. (international handbook series on entrepreneurship). New York, NY: Springer New York, pp.47-76.

Faist, T. (2008). Migrants as Transnational Development Agents: An Inquiry into the Newest Round of the Migration - Development Nexus, Population, Space and Place, 14, pp. 21 42.

Fate Foundation (2016). Mapping Study of Nigeria's Entrepreneurship Ecosystem. Available from: $\quad$ https://www.fatefoundation.org/download/mapping-nigerias-entrepreneurshipecosystem/

Fuller-Love, N. \& Akiode, M. (2020). Transnational entrepreneurs' dynamics in entrepreneurial ecosystems: A critical review, Journal of Entrepreneurship and Innovation in Emerging Economies, 6(1), 41-66. DOI: https://doi.org/10.1177/2393957519881921.

Gnyawali, D. R. \& Fogel, D.S. (1994). Environments for entrepreneurship development: key dimensions and research implications. Entrepreneurship Theory and Practice, 18(4), 43-62.

Henrekson, M. \& Stenkula, M. (2010). Entrepreneurship and public policy, In Ács, Z.J. and Audretsch, D.B. (eds.) Handbook of entrepreneurship research: An Interdisciplinary survey and introduction (International handbook series on entrepreneurship). New York, NY: Springer. pp. 595-637.

Jones, M.V., Coviello, N., \& Tang, Y.K. (2011). International entrepreneurship research (19892009): A domain ontology and thematic analysis. Journal of Business Venturing, 26(6), 632-659.

Kemalbay, G. \& Korkmazoğlu, O.B. (2014). Categorical Principal Component Logistic Regression: A Case Study for Housing Loan Approval, Procedia - Social and Behavioral Sciences, 109, 730 - 736.

Kuckertz, A. (2019). Let's take the entrepreneurial ecosystem metaphor seriously! Journal of Business Venturing Insights, 11, e00124. DOI: https://doi.org/10.1016/j.jbvi.2019.e00124.

Mack, E., \& Meyer, H. (2016). The evolutionary dynamics of entrepreneurial ecosystems, Urban Studies, 53(10), 2118-2133. DOI: https://doi.org/10.1177/0042098015586547. 
National Bureau of Statistics (2010) National poverty rates for Nigeria: 2003-04 (Revised) and 2009-2010 (Abridged Report). Accessed online 10/02/2020. Available from: https://nigerianstat.gov.ng/download/544

Ramachandran, J., Pant, A. \& Pani, S.K. (2012). Building the BoP producer ecosystem: The evolving engagement of Fabindia with Indian handloom artisans, Journal of Product Innovation Management, 29(1), 33-51. DOI: https://doi.org/10.1111/j.15405885.2011.00877. $x$.

Prahalad, C.K. (2012). Bottom of the pyramid as a source of Breakthrough Innovations. Journal of Product Innovation Management, 29(1), 6-12. DOI: https://doi.org/10.1111/j.15405885.2011.00874. $x$.

Reficco, E. and Márquez, P. (2012) Inclusive networks for building BOP Markets. Business \& Society, 51(3), 512-554.

Sautet, F. (2013) Local and systemic entrepreneurship: solving the puzzle of entrepreneurship and economic development, Entrepreneurship Theory and Practice, pp. 387-402. DOI: https://doi.org/10.1111/j.1540-6520.2011.00469. x.

Spigel, B. (2017). The relational organization of entrepreneurial ecosystems. Entrepreneurship Theory and Practice, 41(1), 49-72.

Stam, E. (2015) Entrepreneurial Ecosystems and Regional policy: A Sympathetic Critique. European Planning Studies, 23 (9), 1759-1769.

Stam, E. \& van de Ven, A. (2021) Entrepreneurial ecosystem elements, Small Business Economics. 56(2), 809-832. DOI: https://doi.org/10.1007/s11187-019-00270-6.

Venkataraman, S. (1997) The distinctive domain of entrepreneurship research: An editor's perspective. In J. Katz, \& R. Brockhaus (Eds.), Advances in Entrepreneurship, Firm Emergence and Growth, 3: 119-138. Greenwich, CT: JAl Press. 